\title{
Main Hematological Alterations Found in Patients Affected by New Coronavirus Infection
}

\author{
Shisleide Kilma Verçosa da Silva Fonseca ${ }^{1}$, Andrezza Fabianni Pedrosa dos Santos Lima ${ }^{2}$, Emilly \\ Tainá Batista da Silva ${ }^{3}$, Emivaldo Batista da Silva ${ }^{4 *}$, Joana Bulhões Alvares da Silva Lima ${ }^{5}$, Maria \\ Caroline da Silva ${ }^{6}$, Thais Gomes da Silva ${ }^{7}$, Thacyla Emanuely Santo Alves ${ }^{8}$, Brenda Júlia de Santana \\ Bezerra ${ }^{9}$, Marluce Barbosa da Silva ${ }^{10}$, Anne Mayara do Carmo Matias de Lima ${ }^{11}$, Emanuella Barros \\ de Souza Oliveira Alvares ${ }^{12}$
}

1 Department of Biomedicine, Centro Universitário da Vitória de Santo Antão (UNIVISA), Vitória de Santo Antão, Pernambuco, Brazil. 2,7,8 Department of Nutrition, University Center of Vitória de Santo Antão (UNIVISA), Vitória de Santo Antão, Pernambuco, Brazil

3 Department of Biomedicine, Post-Graduation in Laboratory Clinical Microbiology (ASCES- UNITA) Caruaru - PE

4,5,6,9 Department of Pharmaceutical Sciences, University Center of Vitória de Santo Antão - (UNIVISA) Vitória de Santo Antão, Brazil.

10 Department of Biomedicine, Post-Graduation in Clinical Cytology (FACEAT- Faculty Center for Advanced Studies and Technology) Recife - PE

11 Department of Dentistry, Tiradentes University Center (UNIT-PE) Recife - PE

12 Department of Biology, Center for Biological Sciences, Professor of the Degree Course in Biology, University Center of Vitória de Santo Antão (UNIVISA), Vitória de Santo Antão, Brazil

E-mail adresses: shisleidevercosafonseca@gmail.com1 (Shisleide Kilma Verçosa da Silva Fonseca), andrezzafpslima@hotmail.com2 (Andrezza Fabianni Pedrosa dos Santos Lima), emilly.taina@hotmail.com3 (Emilly Tainá Batista da Silva), emivaldobatista4@gmail.com4 (Emivaldo Batista da Silva), joanafarmacia2018@gmail.com5 (Joana Bulhões Alvares da Silva Lima), maria.201819008@univisa.edu.br6 (Maria Caroline da Silva), thaisgabrieli2@hotmail.com 7 (Thais Gomes da Silva), thacylasantos2020@gmail.com8 (Thacyla Emanuely Santos Alves), brenda.2018286022@univisa.edu.br 9 (Brenda Júlia de Santana Bezerra), marluceacd@yahoo.com.br10 (Marluce Barbosa da Silva), anne1996.am@gmail.com11 (Anne Mayara do Carmo Matias de Lima), emanuella.barros@hotmail.com12 Emanuella Barros de Souza Oliveira Alvares

${ }^{*}$ Corresponding author

\section{To cite this article:}

Fonseca, S.K.V.S.; Lima, A.F.P.S.; Silva, E.T.B.; Silva, E.B.; Lima, J.B.A.S.; Silva, M.C.; Silva, T.G.; Alvez, T.E.S.; Bezerra, B.J.S.; Silva, M.B.; Lima, A.M.C.M.; Álvares, E.B.S.O. Main Hematological Alterations Found in Patients Affected by New Coronavirus Infection. International Journal of Sciences. Vol. 3, No. 1, 2022, pp.19-28. ISSN 2763-5392.

Received: 11 24, 2021; Accepted: 12 26, 2021; Published: 01 15, 2022

\begin{abstract}
Covid-19 is a highly infectious disease caused by the new Coronavirus, which was identified in Wuhan in China and caused covid-19, 11,821 cases and 259 deaths were recorded in the first 30 days of infection, it is known that the disease causes clinical changes, so hematology is a type of test that analyzes information about the types and amounts of components in the blood as: Red blood cells; White blood cells; Platelets. The present study aimed to present the main hematological alterations found in patients hospitalized by Covid-19. The most prevalent mild symptoms include fever and cough, while in severe patient's respiratory failure occurs, so it is possible to observe in the blood test a significant decrease $(10 \%-20 \%)$ of oxygen saturation. However, it was observed that there was a prevalence of changes related to leukocytes and platelets, however, lymphopenia was also present in reports made by authors.
\end{abstract}

Keywords: Covid-19. Epidemiology. Hematology. Clinical Manifestations

\section{Introduction}

Covid-19 is a highly infectious disease caused by the new Coronavirus associated with severe acute respiratory syndrome 2 (SARS-CoV-2). In December 2019, this new virus was transmitted, which was identified in Wuhan, China and caused Covid-19, and then spread and transmitted quickly from person to person worldwide (VIEIRA, 2020). 
2 Fonseca, S.K.V.S.; Lima, A.F.P.S.; Silva, E.T.B.; Silva, E.B.; Lima, J.B.A.S.; Silva, M.C.; Silva, T.G.; Alvez, T.E.S.; Bezerra, B.J.S.; Silva, M.B.; Lima, A.M.C.M.; Álvares, E.B.S.O. Main Hematological Alterations Found in Patients Affected by New Coronavirus Infection ...

Since 2019, when the first case arose, the virus has spread rapidly, in the first 30 days, China recorded 11,821 cases and 259 deaths. (SAMPAIO, 2020). In January 2020, the World Health Organization (WHO) considered the disease as an important international health crisis (HALLAL et al, 2020).

In relation to the first reported and confirmed cases, in Brazil occurred in February, and several actions were used with the intention of reducing the progress of the disease. On February 3, 2020, the country declared A Public Health Emergency of National Importance (ESPIN), in March, who said there was a global pandemic with about 118,000 cases in 114 countries and territories, in April the number of new cases was already approaching 2 million in almost all countries, and more than 100,000 confirmed deaths worldwide (HALLAL et $a l, 2020$; BRAZIL, 2020).

A few months after the discovery of the virus, the number of confirmed cases worldwide reached more than 23 million people, and just over 800,000 deaths by the end of August 2020. In the same period, the United States led the world ranking, both of confirmed cases $(5,755,002)$, and of deaths, $(177,773)$, and Brazil occupied the 2nd position in total cases $(3,622,861)$, and 2 nd position in total deaths $(115,309)$ (LIMA et al, 2021).

Covid-19 causes clinical changes that vary according to each individual's organism, the most prevalent and mild symptoms include fever and cough, while the most serious symptoms are respiratory failure and chest pains. Diagnosis can be made through a medical consultation, but for better confirmation it is necessary to perform laboratory tests. Hematology is one of the crucial tests in this investigation, it studies the elements that make up blood such as: Red blood cells; Leukocytes; Platelets; The objective of hematological analysis is to identify if there are changes in these elements, such as lymphopenia, lymphocytosis and thrombocytopenia. In addition to its use to establish a diagnosis, it is used for the follow-up of patients diagnosed with Covid-19 (AZEVEDO, 2020).

The choice of the theme proposed a differentiated look at Hematology because this area of activity is extremely important for concrete diagnoses, considering that this technology is also present in the follow-up of patients hospitalized by Covid-19. This literature review aimed to present the main hematological alterations found in patients affected by infection of the new coronavirus, and to report the most prevalent symptoms of Covid-19.

\section{Methodology}

This is a bibliographic review study, that is, a survey of theoretical reference from scientific publications, which is nationally and internationally involving the main clinical manifestations and hematological effects found in patients affected by infection of the new coronavirus.

The data collection occurred through the Coordination for the Improvement of Higher Education Personnel (CAPES) and Google Academic.

The research began in April 2020 by the inclusion criteria: works in English and Portuguese, published in the last five years, which deal with topics related to involving the main clinical manifestations and hematological effects found in patients affected by infection of the new coronavirus. These, available for free online. Exclusion criteria include: works whose text is not available in full, duplicated, review, metaanalysis, and also works that, after reading, were not related to the research objective.

Regarding the data appreciation, this was performed qualitatively, prioritizing the analysis of micro processes, understanding, interpreting and dialing these findings, interrelating them, through the established criteria.

Therefore, all rules related to ethics and copyright were obeyed, since as a result of the bibliographic characteristic of this study, it was not necessary to evaluate by the Research Ethics Committee.

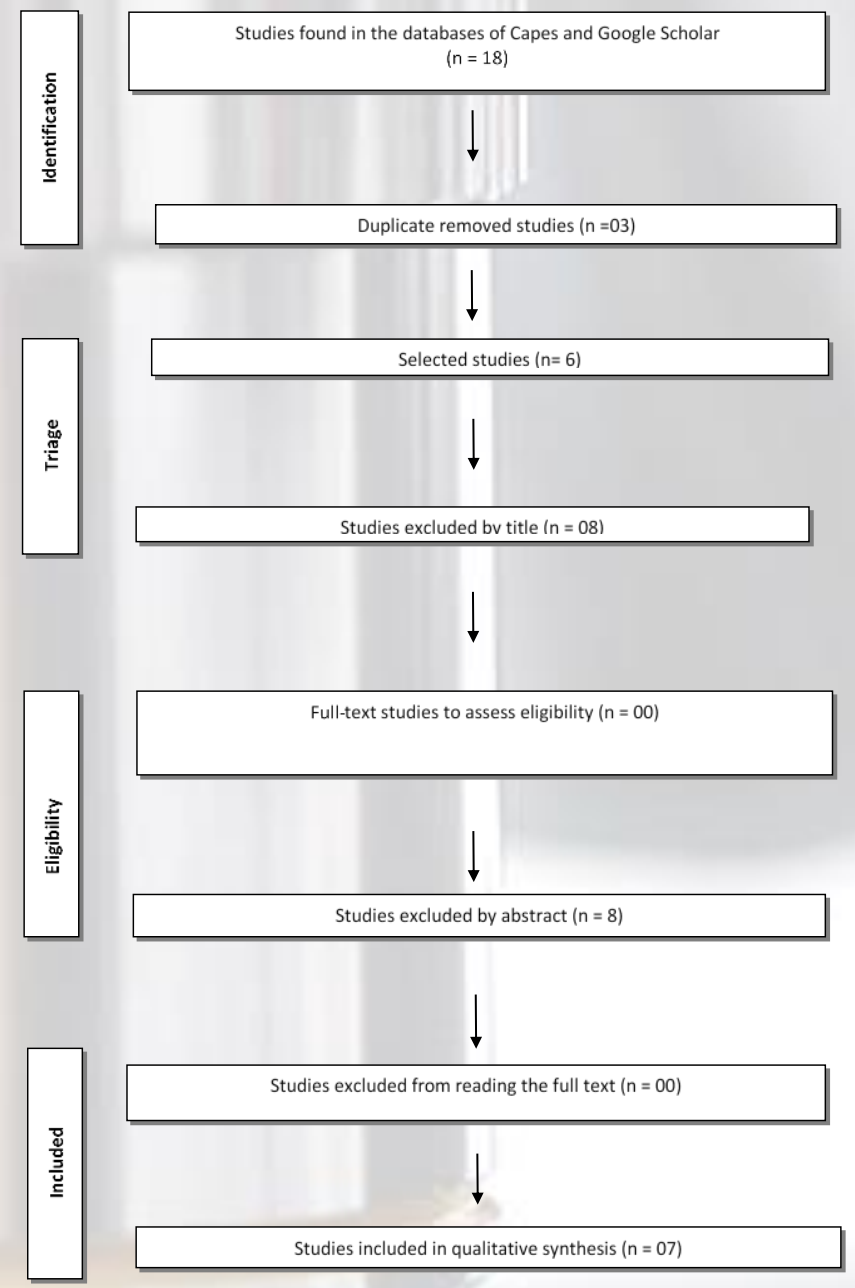

Figure 1. Flowchart of Selection Criteria and inclusion of studies

\section{Results and Discussion}

Regarding the results found, a total of 18 works were analyzed, but only 07 works were included in the research, respecting the inclusion criteria. 


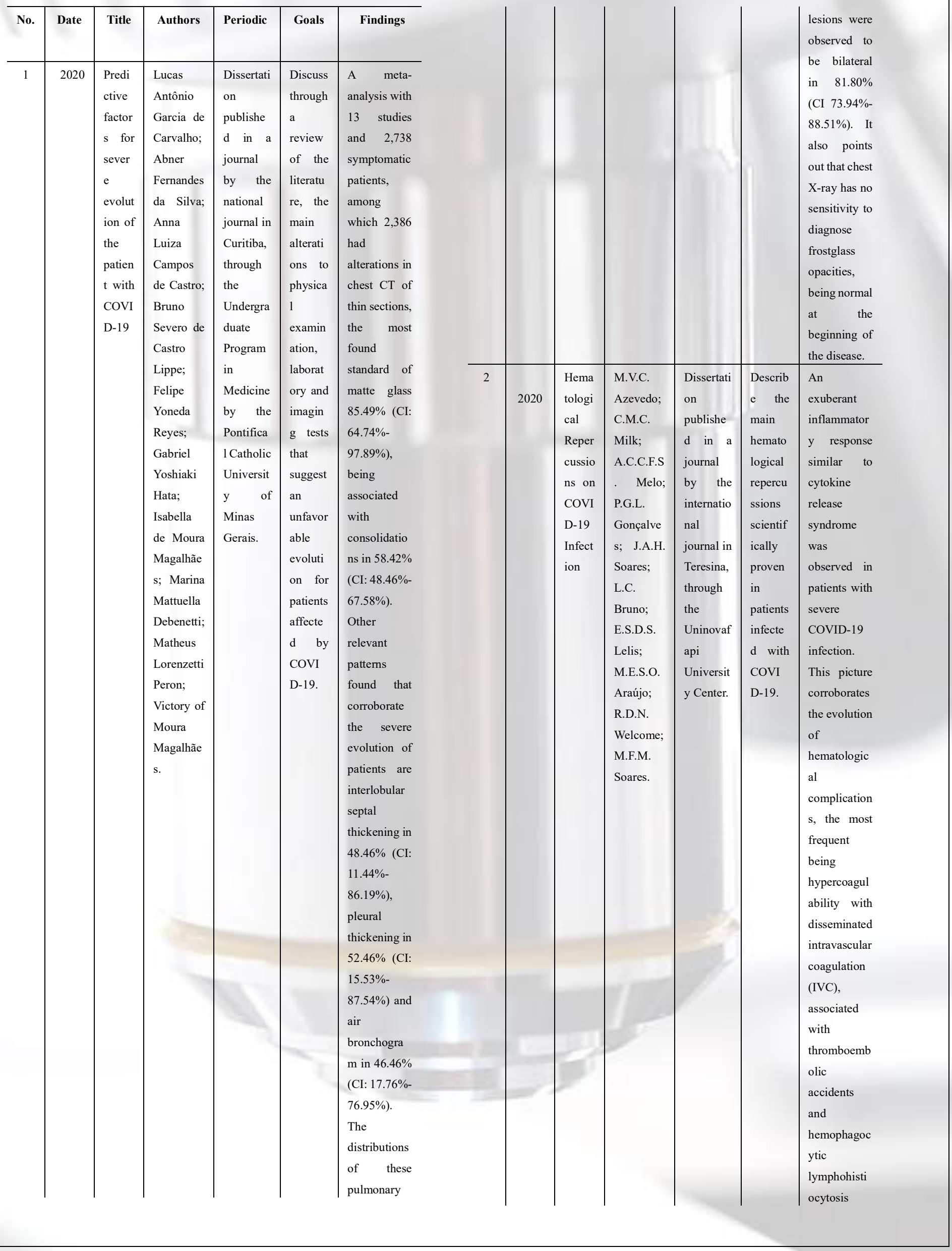


4 Fonseca, S.K.V.S.; Lima, A.F.P.S.; Silva, E.T.B.; Silva, E.B.; Lima, J.B.A.S.; Silva, M.C.; Silva, T.G.; Alvez, T.E.S.; Bezerra, B.J.S.; Silva, M.B.; Lima, A.M.C.M.; Álvares, E.B.S.O. Main Hematological Alterations Found in Patients Affected by New Coronavirus Infection ...

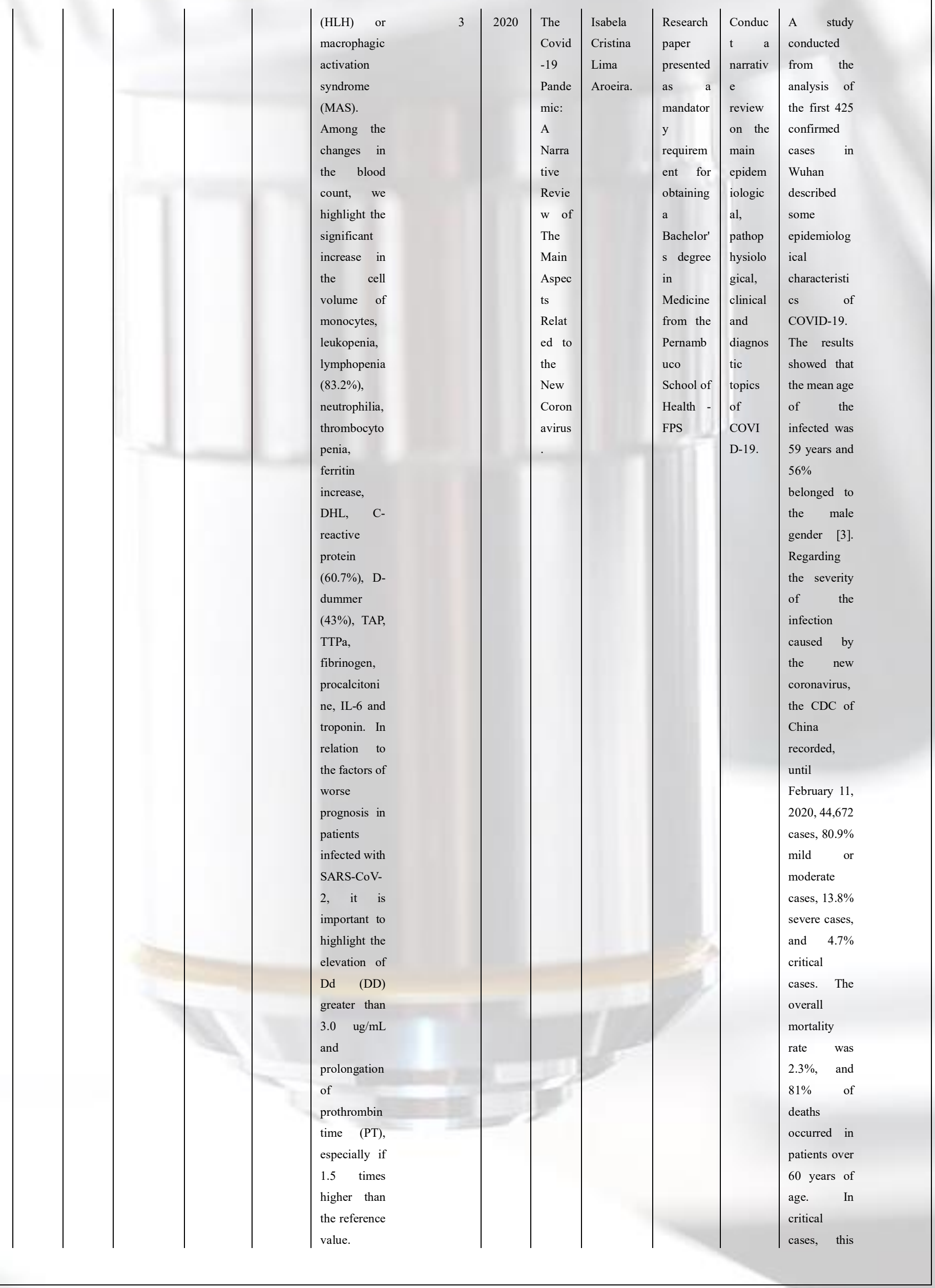




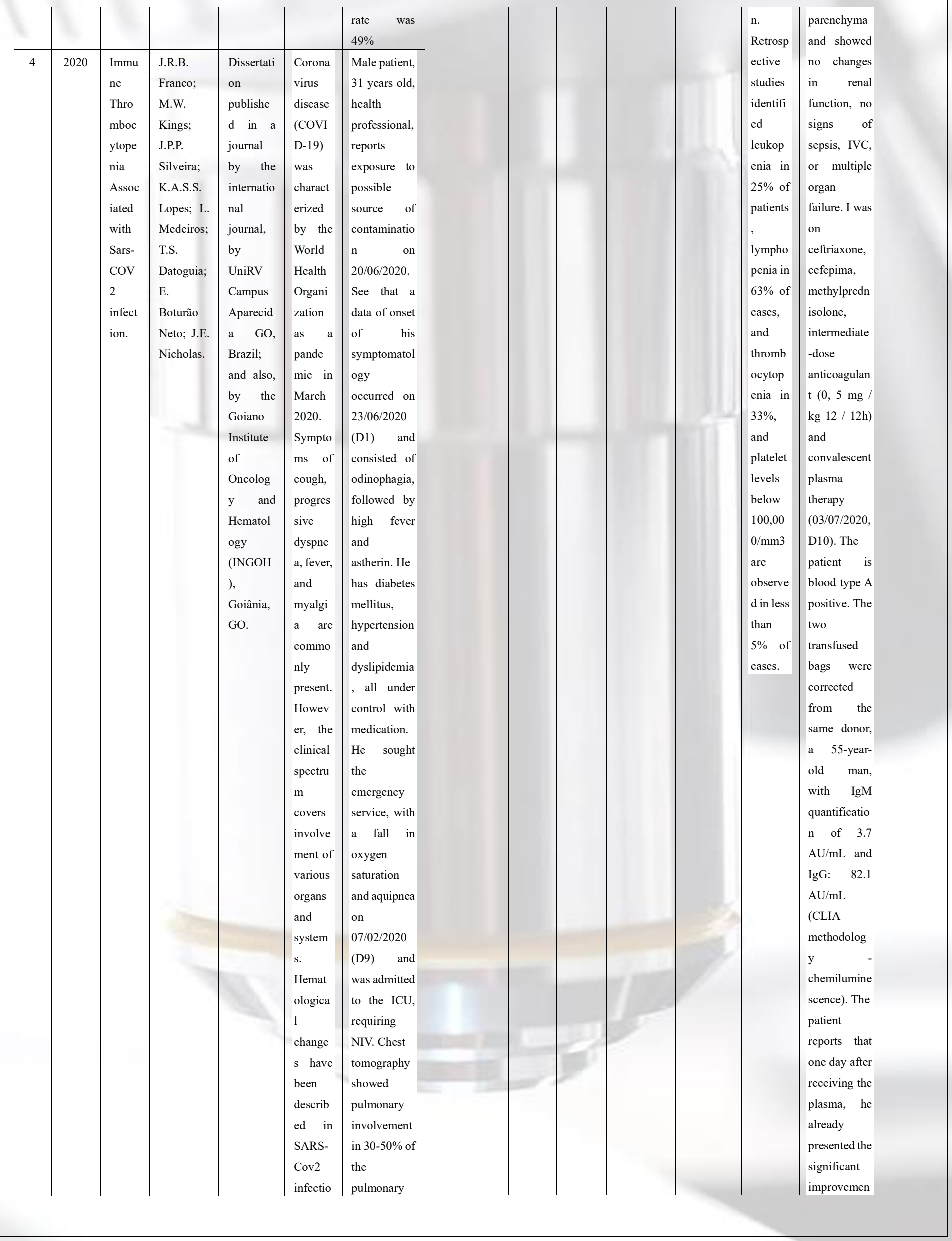


6 Fonseca, S.K.V.S.; Lima, A.F.P.S.; Silva, E.T.B.; Silva, E.B.; Lima, J.B.A.S.; Silva, M.C.; Silva, T.G.; Alvez, T.E.S.; Bezerra, B.J.S.; Silva, M.B.; Lima, A.M.C.M.; Álvares, E.B.S.O. Main Hematological Alterations Found in Patients Affected by New Coronavirus Infection ...
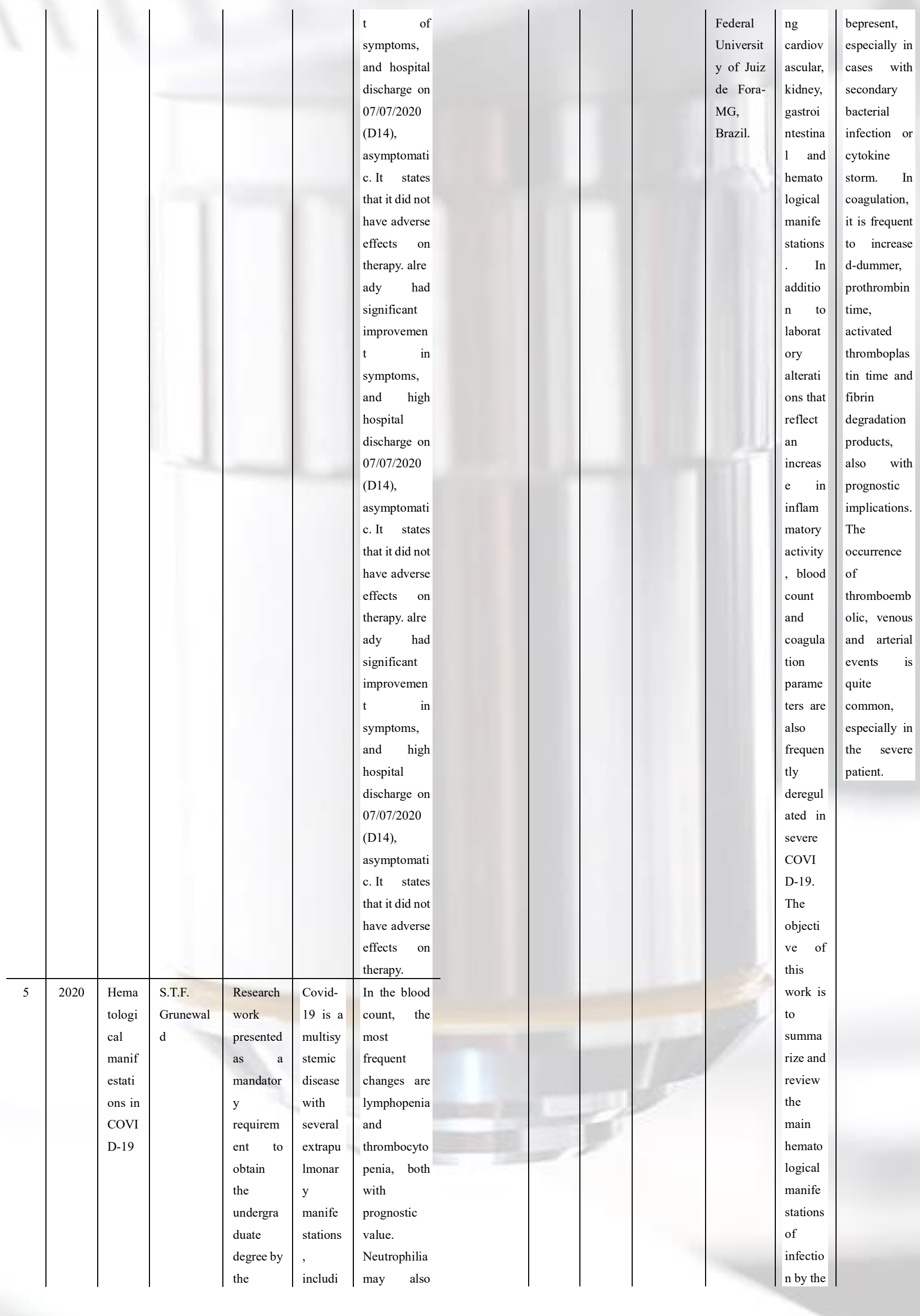


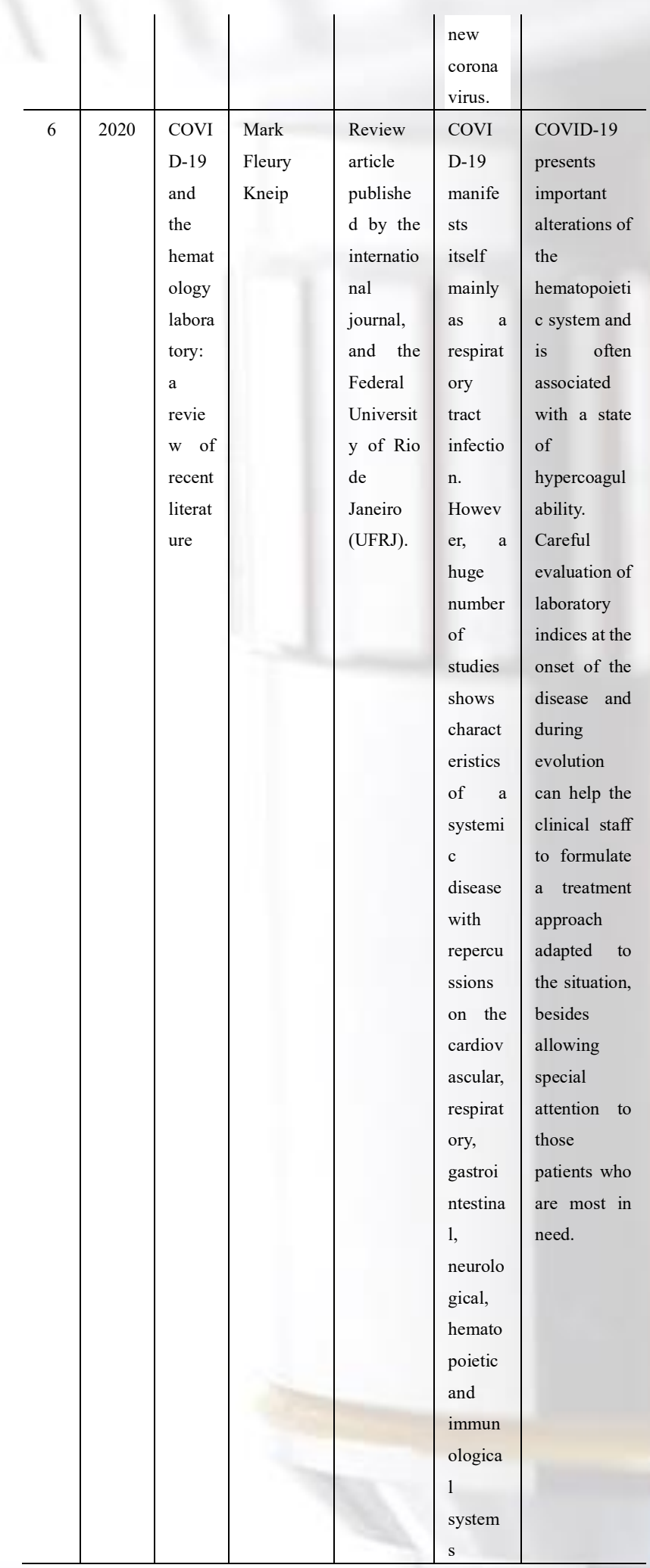

\begin{tabular}{|c|c|c|c|c|c|c|}
\hline 7 & 2020 & $\begin{array}{l}\text { A } \\
\text { Repor } \\
\mathrm{t} \text { of } \\
\text { Exper } \\
\text { ience } \\
\text { of } \\
\text { Profe } \\
\text { ssiona } \\
\text { ls } \\
\text { Insert } \\
\text { ed in } \\
\text { the } \\
\text { Expa } \\
\text { nded } \\
\text { Cente } \\
\mathrm{r} \text { of } \\
\text { Interp } \\
\text { rofess } \\
\text { ional } \\
\text { Care } \\
\text { Durin } \\
\mathrm{g} \text { the } \\
\text { Emer } \\
\text { gence } \\
\text { of } \\
\text { COVI } \\
\text { D-19. }\end{array}$ & $\begin{array}{l}\text { Cleverson } \\
\text { Felipe da } \\
\text { Silva } \\
\text { Ferreira; } \\
\text { Bruna } \\
\text { Kérsia } \\
\text { Vasconcel } \\
\text { os Santos; } \\
\text { Jane } \\
\text { Eduarda } \\
\text { of Lira } \\
\text { Moura; } \\
\text { Monalisa } \\
\text { Ferreira } \\
\text { de } \\
\text { Vasconcel } \\
\text { os; } \\
\text { Lysrayane } \\
\text { Kerullen } \\
\text { David } \\
\text { Barroso; } \\
\text { Ana } \\
\text { Lorena } \\
\text { Madeiro } \\
\text { de Lima; }\end{array}$ & $\begin{array}{l}\text { Paper } \\
\text { Publishe } \\
\text { d by E- } \\
\text { Publish- } \\
\text { Science } \\
\& \\
\text { Health: } \\
\text { Updates } \\
\text { on } \\
\text { COVID- } \\
19 .\end{array}$ & $\begin{array}{l}\text { The } \\
\text { objecti } \\
\text { ve of } \\
\text { this } \\
\text { work is } \\
\text { to } \\
\text { reflect } \\
\text { on the } \\
\text { multipr } \\
\text { ofessio } \\
\text { nal } \\
\text { perfor } \\
\text { mance } \\
\text { in the } \\
\text { Expand } \\
\text { ed } \\
\text { Interpr } \\
\text { ofessio } \\
\text { nal } \\
\text { Care } \\
\text { Center } \\
\text { (NACI) } \\
\text {, in a } \\
\text { Psychia } \\
\text { tric } \\
\text { Hospita } \\
\text { lization } \\
\text { Unit in } \\
\text { the city } \\
\text { of } \\
\text { Sobral- } \\
\text { CE }\end{array}$ & $\begin{array}{l}\text { In the } \\
\text { experience } \\
\text { report, it is } \\
\text { discussed } \\
\text { about the } \\
\text { creation and } \\
\text { composition } \\
\text { of NACI, as } \\
\text { well as the } \\
\text { use of care } \\
\text { management } \\
\text { during } \\
\text { activities and } \\
\text { experiences } \\
\text { from inter } \\
\text { professionali } \\
\text { ty. }\end{array}$ \\
\hline
\end{tabular}

Therefore, it is noticed that there is no predilection about the choice of the journal for publication on the theme chosen in the period studied. In addition, it was observed that the papers dealing with the subject were scientific articles.

Finally, in the following sections we have the main points that the authors consulted discuss about the main clinical manifestations and hematological effects found in patients affected by infection of the new coronavirus.

Regarding the record of the first case confirmed by Covid-19 in Latin America, this occurred in Brazil, a 61year-old Brazilian who had visited Lombardy in northern Italy, returned to the country, specifically to São Paulo on February 21, 2020, one month after the first confirmed case in the country, all states reported cases of the new Coronavirus (FERREIRA NETTO, 2020).

Six months after the first recorded case of Covid-19 in China, 216 countries were hit by the new Coronavirus, in 2020 in June, the 22nd, the world recorded 8,860,331 cases and 465,740 deaths. Among the many countries most affected were the United States, on this same date, recorded 119,923 deaths and 2,275,645 of contaminated people (MARTIN et al, 2020).

When analyzing the regions of America in 2020, in April, May and June, it was observed that the United States, 
8 Fonseca, S.K.V.S.; Lima, A.F.P.S.; Silva, E.T.B.; Silva, E.B.; Lima, J.B.A.S.; Silva, M.C.; Silva, T.G.; Alvez, T.E.S.; Bezerra, B.J.S.; Silva, M.B.; Lima, A.M.C.M.; Álvares, E.B.S.O. Main Hematological Alterations Found in Patients Affected by New Coronavirus Infection ...

Ecuador and Canada had the highest number of cases in April. Brazil and Chile had the highest number of cases in June. In relation to deaths, in the United States there were more deaths in April, while in Canada and Ecuador there were more deaths in May, Chile and Brazil occurred more deaths in June (Table 1) (GOMES et al, 2020).

Table 1- Representation of the number of cases and deaths in April, May and June by the reviews of America in 2020 .

\begin{tabular}{ccc}
\hline REGIONS & CASES/MONTH & DEATHS/MONTH \\
\hline Brazil & $25,690 /$ June & $989 /$ June \\
Canada & 1,468/April & 132/May \\
Chile & 5,296/June & $155 /$ June \\
Ecuador & 754/April & May 79 \\
United States & 28,778/April & $1,668 /$ April
\end{tabular}

Source: Adapted from GOMES, Guilherme Gallo Costa et al. Epidemiological profile of the New Infectious Disease of Coronavirus-COVID-19 (Sars-Cov-2) in the world: Descriptive study, January-June 2020.

The degree of epidemiology of Covid-19 differs according to the country and its regions, because each country, state, and city, establish its preventive measures, the regions of Brazil, for example, the southeast region has always led with the highest number of cases, already the northeast region in second place, following the north, south and Midwest (SOUZA et al, 2021).

A study with a goal of analysis involving the clinical status of patients from different studies showed the following symptoms: fever $(88.3 \%)$; cough $(68.6 \%)$; myalgia $(35.8 \%)$; expectoration (23.2\%); dyspnea $(21.9 \%)$; headache $(12.1 \%)$; diarrhea (4.8\%) and nausea (3.9\%) (Table 2). It was observed that fever was the symptom that was most present in most patients, while diarrhea and nausea were not prevalent symptoms (XAVIER, 2020).

Table 2- Percentage of symptoms presented by patients in the study with ametanalysis.

\begin{tabular}{cc}
\hline Symptoms & Percentage \\
\hline Fever & $88,3 \%$ \\
Cough & $68,6 \%$ \\
Myalgia & $35,8 \%$ \\
Expectoration & $23,2 \%$ \\
Dyspnoea & $21,9 \%$ \\
Headache & $12,1 \%$ \\
Diarrhoea & $4,8 \%$ \\
Nausea & $3,9 \%$ \\
Total & $100 \%$ \\
\hline
\end{tabular}

Source: Own author, 2021.

Another study evaluated the symptoms in 1117 children under the age of 18 years, in view of the clinical manifestations, the symptom that was most present was fever
(47.5\%), followed by cough $(41.5 \%)$, runny nose $(11.2 \%)$, diarrhea $(8.1 \%)$, nausea $(7.1 \%)$, fatigue $(5.0 \%)$ and respiratory difficulty $(3.5 \%)$. Some more severe symptoms were identified, 145 children were diagnosed with pneumonia and 43 had their upper airways infected (ALMEIDA, 2021).

Regarding infection, children have the same probability as adults, however, symptoms present differently, in infected children the symptoms of Covid-19 present mildly and often the infection is asymptomatic. When symptomatic children present mostly low fever and cough associated with some gastrointestinal symptoms including abdominal pain diarrhea and nausea, usually recovery lasts on average 14 days (ZIMMERMANN, 2020).

Usually, $80 \%$ of infected people recover without needing hospital treatment, usually clinical manifestations start as a common cold and soon after the individual has fever, cough, headache, fatigue, throat infection, headache, myalgia, loss of taste and smell, however, the most common symptoms reported by authors are fevers and cough. On average $25 \%$ of cases occur to atypical pneumonia and respiratory deterioration, in addition to respiratory symptoms, some patients in mild state present digestive manifestations (GOULARTE,2020).

Hematology is a type of test that analyzes specific information about the types and amounts of components in the blood, such as: Red blood cells (red blood cells); White blood cells (leukocytes); Platelets (blood clotting). It is known that coronavirus mainly affects the lungs, however, it causes laboratory changes that can be perceived in a blood count. Initially in the first week of infection, lymphocytes are the main affected by the virus, in the second week this change becomes even more worrying, even in the first 14 days the patient may present albumin fall due to increased permeability of blood capillaries resulting from the inflammatory process (FLEURY, 2020).

In patients in the intermediate phase of the disease, the blood test presents a large decrease in oxygen, which causes an elevation of lactate dehydrogenase (LDH) and lactate. In severe patients, respiratory failure occurs, so it is possible to observe in the blood test a significant decrease (10\% - 20\%) of oxygen saturation. The lack of oxygen in the blood is a serious condition, which can cause severe tissue damage and, consequently, the risk of death (MARTINS, 2021).

In an analysis performed by (ZANCANARO, 2020), it showed that in leukocyte alterations, $75 \%$ of patients with mild symptoms had normal lymphocytes, $31.6 \%$ had Lymphopenia (low level of lymphocytes in the blood), and severe patients presented Leukocytosis that can be defined as increasing the number of leukocytes, is a response of the organism to an infection.

Most hematological findings in infections by the new coronavirus are related to leukocytes, our body's defense cells and platelets, coagulation-related cells (Image 1) (CÂNDIDO, 2021). It is possible to observe that changes related to leukocytes and platelets have a higher prevalence, causing leukopenia and thrombocytopenia, respectively. 
Tabela 2: Alteraç̃̃es hematológicas mais comuns e com valor prognóstico em casos de infecção por SARS COV-2. [Hb]: Concentração de hemoglobina. TP: Tempo de protrombina. VHS: Velocidade de Hemossedimentaçăo. (Fonte: Autoria própria).

\begin{tabular}{|c|c|c|c|c|}
\hline Parâmetros avaliados & \multicolumn{4}{|c|}{$\begin{array}{l}\text { Quantitativo de artigos que relataram alterações para cada } \\
\text { parâmetro avaliado }\end{array}$} \\
\hline \multirow[t]{2}{*}{ Sexo dos indivíduos } & $\begin{array}{c}\text { Mais de } 50 \% \text { dos } \\
\text { individuos era do sexo } \\
\text { masculino }\end{array}$ & \multicolumn{2}{|c|}{$\begin{array}{c}\text { Mais de } 50 \% \text { dos } \\
\text { indivíduos era do sexo } \\
\text { feminino }\end{array}$} & Não informado \\
\hline & 6 & \multicolumn{2}{|c|}{1} & 7 \\
\hline \multirow[t]{2}{*}{ Alterações nas hemácias } & Diminuição da [Hb] & \multicolumn{2}{|c|}{$\begin{array}{l}\text { Aumento da VHS e } \\
\text { diminuição da [Hb] }\end{array}$} & Não informado \\
\hline & 2 & \multicolumn{2}{|c|}{2} & 10 \\
\hline \multirow{2}{*}{ Alterações nas plaquetas } & \multicolumn{2}{|c|}{ Trombocitopenia } & \multicolumn{2}{|c|}{ Não informado } \\
\hline & \multicolumn{2}{|l|}{11} & \multicolumn{2}{|r|}{3} \\
\hline \multirow[t]{2}{*}{ Alterações nos leucócitos } & \multicolumn{2}{|c|}{$\begin{array}{l}\text { Linfócitos associados com } \\
\text { leucopenia }\end{array}$} & \multicolumn{2}{|c|}{ Aumento dos neutrófilos } \\
\hline & \multicolumn{2}{|l|}{11} & \multicolumn{2}{|r|}{5} \\
\hline \multirow{2}{*}{ Alterações na coagulação } & D-Dímero & \multicolumn{2}{|c|}{ D-Dímero e TP } & Não informado \\
\hline & 4 & \multicolumn{2}{|c|}{4} & 6 \\
\hline
\end{tabular}

Figure 2. Representation of the sampling of the study on hematological alterations associated with Covid-19 in Patients. Source: CÂNDIDO, Hematological Alterations Associated with Covid-19 in Patients, 2021.

Patients in severe and critical condition have an insufficient immunological response pattern, however, presents neutral cytosis with morphological changes including changes in granulocytes and monocytes, besides presenting cytopenia lymph $(-20 \%)$ in the blood count, because the degradation of the lymphatic system ends up causing morphological changes and lymphocytic dysfunction. Neutrophils and $\mathrm{B}$ and $\mathrm{T}$ lymphocytes and killer natural cells will produce high levels of proinflammatory cytokines and chyosins and thus the inflammatory picture ends up aggravating lymphocytic and tissue dysfunction causing a deficiency in the function of organs affected mainly by the lungs (GRUNEWALD, 2020).

The Chinese population infected with covid-19 has demonstrated the presence of leukopenia, i.e., low levels of white blood cells, besides presenting moderate lymphopenia and may progress too severe. The most frequent hematological alteration is the low level of lymphocytes, that is, lymphopenia, because it functions as a biomarker of the severity of the infection. However, lymphocytes can be used in screening to aid in diagnosis and also in monitoring the evolution of severe cases by covid-19 (PEREIRA, 2021).

\section{Conclusion}

The study of the main hematological alterations found in patients affected by infection of the new coronavirus, epidemiological data indicate that the virus reached more than 23 million people, and just over 800,000 deaths by the end of August 2020, in this same period the United States was the country that suffered the most from the consequences of the pandemic, occupying the first place in the world ranking of confirmed cases and deaths. In Brazil, the Southeast region led the ranking of cases confirmed by Covid-19.

Therefore, it was observed that symptoms in patients in mild state comprise mostly fever and cough, while in patients in severe condition occurs to respiratory failure. It is known that coronavirus causes hematological alterations that can be perceived in a blood count, from the data collection it was observed that there was a prevalence of alterations related to leukocytes and platelets, however, lymphopenia is defined as low level of lymphocytes, was also present in reports made by authors.

\section{References}

[1] VIEIRA, Luisane Maria Falci; EMERY, Eduardo; ANDRIOLO, Adagmar. COVID-19-Diagnóstico Laboratorial para Clínicos. 2020. Escola Paulista de Medicina da Universidade Federal de São Paulo, São Paulo, 2020.

[2] SAMPAIO, Carla Jaqueline Silva. Covid-19: etiologia, aspectos clínicos, diagnóstico, tratamento e epidemiologia. Revista Saúde. com, Bahia, v. 16, n. 2, 2020.

[3] HALLAL, Pedro Curi, et al. Evolução da prevalência de infecção por COVID-19 no Rio Grande do Sul, Brasil: inquéritos sorológicos seriados. Ciência \& Saúde Coletiva, Rio de Janeiro, v. 25, p. 2395-2401. Jun., 2020.

[4] BRASIL. (2020). Doença pelo coronavírus 2019. Especial Vigilância Epidemiológica Laboratorial. TBoletim Epidemiológico. In Ministério da Saúde. São Paulo, v. 23, p. e200021, ago., 2020.

[5] LIMA, Francisca Elisângela Teixeira et al. Intervalo de tempo decorrido entre o início dos sintomas e a realização do exame para COVID-19 nas capitais brasileiras, agosto de 2020. Epidemiologia e Serviços de Saúde, Brasília, v. 30, p. e2020788, dez, 2020.

[6] AZEVEDO, MVC et al. Repercussões hematológicas na infecção por covid-19. Hematology, Transfusion and Cell Therapy, Teresina, v. 42, p. 555, 2020.

[7] FERREIRA NETTO, Raimundo Gonçalves; DO NASCIMENTO CORREAA, José Wilson. Epidemiologia do surto de doença por coronavírus (covid-19). DesafiosRevista Interdisciplinar da Universidade Federal do Tocantins, Manaus, v. 7, n. Especial-3, p. 18-25, 2020.

[8] MARTIN, Pollyanna et al. História e Epidemiologia da COVID-19. Ulakes journal of medicine, Estados Unidos, v. 1, p. 11-22, jul, 2020.

[9] GOMES, Guilherme Gallo Costa et al. Perfil epidemiológico da Nova Doença Infecciosa do Coronavírus-COVID-19 (Sars-Cov-2) no mundo: Estudo descritivo, janeiro-junho de 2020. Brazilian Journal of Health Review, Curitiba, v.3, n. 4, p. 7993-8007, 2020.

[10] SOUZA, Alex Sandro Rolland et al. Aspectos gerais da pandemia de COVID-19. Revista Brasileira de Saúde Materno Infantil, v. 21, p. 29-45, fev, Pernambuco, 2021.

[11] XAVIER, Analucia R. et al. COVID-19: manifestações clínicas e laboratoriais na infecção pelo novo coronavírus. Jornal Brasileiro de Patologia e Medicina Laboratorial, Rio de Janeiro, v. 56, 2020.

[12] ALMEIDA, Sersie Lessa Antunes Costa et al. Manifestações clínicas do Covid-19 na população 
10 Fonseca, S.K.V.S.; Lima, A.F.P.S.; Silva, E.T.B.; Silva, E.B.; Lima, J.B.A.S.; Silva, M.C.; Silva, T.G.; Alvez, T.E.S.; Bezerra, B.J.S.; Silva, M.B.; Lima, A.M.C.M.; Álvares, E.B.S.O. Main Hematological Alterations Found in Patients Affected by New Coronavirus Infection ...

pediátrica e neonatal. Brazilian Journal of Health Review, Curitiba, v. 4, n. 2, p. 4582-4591, 2021.

[13] ZIMMERMANN, Petra; CURTIS, Nigel. COVID-19 in children, pregnancy and neonates: a review of epidemiologic and clinical features. The Pediatric infectious disease journal, Estados Unidos, v. 39, n. 6, p. 469, 2020.

[14] GOULARTE, Pietra dos Santos. et al. Manifestações clínicas, fatores de risco e diagnóstico na COVID-19. Ulakes journal of medicine, São Paulo, v. 1, 2020.

[15] FLEURY, Marcos Kneip. A COVID-19 e o laboratório de hematologia: uma revisão da literatura recente. Revista Brasileira de Análises Clínicas, Rio de Janeiro, v. 52, n. 2, pág. 131-7, 2020.

[16] MARTINS, ML et al. Alterações hematológicas em pacientes com covid-19 hospitalizados: estudo retrospectivo. Hematology, Transfusion and Cell Therapy, Minas Gerais, v. 43, p. S32, 2021.

[17] ZANCANARO, Vilmair et al. Alterações nos parâmetros hematológicos e imunológicos observadas na infecção pelo sars-cov-2: uma revisão sistemática de literatura. Brazilian Journal of Development, Curitiba, v. 7, n. 5, p. 50745-50758, 2021.

[18] CÂNDIDO, Rômulo Franklin de Lima. Alterações hematológicas associadas à COVID-19 em pacientes sintomáticos. 2021, p. 37, (Trabalho de Conclusão de Curso) - Universidade Federal do Rio Grande do Norte. 2021.

[19] GRUNEWALD, S. T. F. Manifestações hematológicas na covid-19. Hematology, Transfusional and Cell Therapy, v. 42 , p. $542,2020$.

[20] PEREIRA, Ana Flávia et al. Alterações hematológicas e hemostasia na COVID-19: uma revisão de literatura. Pesquisa, Sociedade e Desenvolvimento, São Paulo, v. 10, n. 11, pág. e171101119409-e171101119409, 2021. 